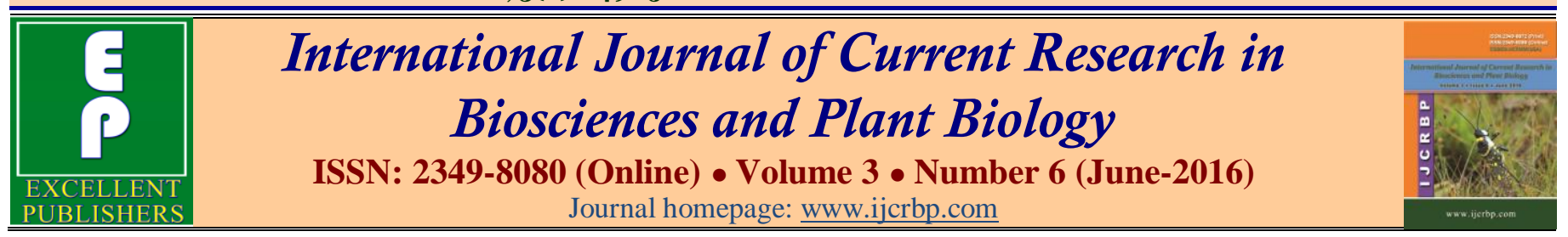

Review Article

doi: http://dx.doi.org/10.20546/ijcrbp.2016.306.018

\title{
Assessment of Chemical and Biological Parameters in Sorghum-Wheat Cropping Sequence under Long Term Fertilization - A Review
}

\author{
Mohana Rao Puli*, R. N. Katkhar, Jayalakshmi Mitnala and Burla Srihari Rao \\ Department of Soil Science and Agricultural Chemistry, Dr. Panjabrao Deshmukh Krishi Vidya Peeth, Akola, M.S., India \\ *Corresponding author.
}

\begin{abstract}
A bstract
Continuous addition of chemical fertilizers poses problems like toxicity due to high amounts of salts as residues of fertilizer and deterioration of the physico-chemical properties. Organic manure ameliorates this problem as organic matter helps in increasing adsorptive power of soil for cations and anions particularly phosphate and nitrate. The continuous use of chemical fertilizers over a long period may cause imbalance in the microbial population and there by indirectly affect the biological properties. The microbial biomass, which is the total sum of all microorganisms present in soil, serves as a temporary sink for nutrients including nitrogen and can be considered as an index of soil fertility. Soil harbours dynamic population of microorganisms, which play major role in decomposition of organic matter and transformation of plant nutrients. The availability of organically bounded nitrogen through transformation in soil to the plant mainly depends on the population of microorganisms, which may be influenced by the application of inorganic fertilizers and organic manure.
\end{abstract}

\section{Article Info}

Accepted: 24 March 2016

Available Online: O6 June 2016

\section{Ke ywords}

Labile carbon

Long term fertilization

Organic manure

Soil microorganisms

\section{Introduction}

Long term fertilization in cropping system plays a key role in maintaining soil physico-chemical and biological conditions. Inorganic fertilization to the soil results in decline in organic carbon content of soil which negatively affects the biological activity in the soil, especially beneficial microbial population. Soil beneficial microorganisms and organic matter content are important for slow release of nutrients in the soil which is essential for crop plants. Organic input to the soil is known to improve soil organic carbon and microbial population. Either alone or in combination of organics with inorganics may help in the revival of soil fertility status thus favouring the crop growth and yield. The present review highlights the chemical and biological parameters in sorghum-wheat cropping sequence under long term fertilization.
Assessment of chemical parameters in sorghumwheat cropping system under long term fertilization

\section{Organic carbon and labile carbon}

Verma et al. (1987) reported that the decline in organic carbon content in soil as a result of continuous intensive rice-wheat rotation without adding organic matter to the soil. However, combined use of organics and inorganics increased the organic carbon status of soil. Kukreja (1991) studied and observed that application of FYM enhanced the organic carbon and total nitrogen. Bhandari et al. (1992) observed that combined use of organics and inorganics increased organic carbon status of soil.

Gupta et al. (1992) reported an increase in organic carbon content of soil with application of FYM and 120 $\mathrm{kg} \mathrm{N}$ per ha. Bhardwaj et al. (1994) reported continuous 
cropping without fertilization led to the depletion of organic carbon and available NPK. Whereas, continuous fertilization had beneficial effect on organic carbon status. Blair et al. (1995) reported that ploughing and cropping of a pasture soil results in a rapid decrease in carbon particularly the more labile fractions.

Tiwari et al. (1995) noted decrease in organic carbon content with profile depth. The decrease was more evident in the $15-30 \mathrm{~cm}$ soil depth because most organic carbon residues remained in the plough layer. Kamalakumari and Singaram (1996) noticed that application of FYM and NPK continuously for 20 years in maize-cowpea-finger millet cropping sequence showed significant increase in organic carbon content of the soil. Whitebread et al. (1996) found only slight increases in total carbon following three years of residue that there was a significant increase in labile carbon.

Eak and Stewart (1998) pointed out that organic carbon did not change significantly during the time period. Ravankar et al. (1998) found that the application of 100\% NPK along with 10 tonnes FYM per ha increased the organic carbon content of Vertisol. Vaidya and Gabhane (1998) showed that organic carbon status of the soil increased with increasing level of fertilizer doses after seventh cycle of sorghum-wheat cropping sequence. They also noticed that combination of fertilizers with FYM increased the organic carbon status of the soil.

Sharma et al. (2000) observed that the organic carbon content increased significantly in treatments having combined application of crop residues, FYM and fertilizer compared to fertilizer alone. Bhattacharyya et al. (2004) reported that the oxidizable soil organic carbon content was maximum in NPK + FYM treatment at 0-15 $\mathrm{cm}$ depth and was significantly more than all other treatments. Sharma et al. (2007) noticed that the organic carbon from the initial level of $14.8 \mathrm{~g} \mathrm{~kg}^{-1}$, declined to $4.9 \mathrm{~g} \mathrm{~kg}^{-1}$ in control plot and $8.4 \mathrm{~g} \mathrm{~kg}^{-1}$ in $100 \% \mathrm{NPK}$ plot. However, use of $100 \%$ NPK + FYM had maintained the level of organic carbon even after 31 years of cultivation.

\section{Total nitrogen and N-mineralization}

Schimel et al. (1985) found that $\mathrm{N}$-mineralization ranged from 0.9 to $1.9 \%$ of total $\mathrm{N}$ and this proportion generally increased on cultivation. Consistantinides and Fownes (1994) found that Nitrogen content in the material favours net mineralization and $\mathrm{N}$ concentration from $<1.7$ to $2.0 \%$ generally causes net immobilization.
Sarkar et al. (1994) reported that the effect of rate of urea application on the loss of nitrogen on an average the magnitude of nitrogen loss was $27 \%$ of applied nitrogen at no gypsum treatment and such effect lowering down the nitrogen loss was more pronounced at higher levels of nitrogen application.

Hutchinson et al. (1995) concluded that denitrification is usually not restricted by enzyme activity but influenced by organic carbon and oxygen availability, presence of nitrogen oxides $\left(\mathrm{NO}_{3}{ }^{-}, \mathrm{NO}_{2}{ }^{-}, \mathrm{NO}\right.$ or $\left.\mathrm{N}_{2} \mathrm{O}\right)$, type of crop residues, degree of decomposition, $\mathrm{NO}_{3}{ }^{-}$supply and soluble carbon supply affect the amount of denitrification gases $\left(\mathrm{NO}, \mathrm{N}_{2} \mathrm{O}, \mathrm{N}_{2}\right.$ ) produced.

Eak and Stewart (1998) reported that the total nitrogen did not change significantly during the time period. Dinesh and Dubey (1999) observed that the Nmineralization rates were greater during the first week and decreased with time in all treatments. On an average, the organic manure amended soil leached $156.3 \mathrm{mg} \mathrm{kg}^{-1}$ more $\mathrm{NO}_{3}^{-}+\mathrm{NO}_{2}^{-}$than that unamended control. The net $\mathrm{N}$-mineralization was however, significantly higher in soils amended with organic manures compared to the unamended control.

Mishra et al. (2001) reported that $\mathrm{N}$ content of the wheat straw increased markedly during $2^{\text {nd }}$ to $10^{\text {th }}$ week and witnessed little change thereafter during first two weeks 23.8 and $29.3 \%$ of the total $\mathrm{N}$ present in the wheat straw was mineralized in case of absence and presence of green manure treatments, respectively. Then they concluded that the incorporation of wheat straw before 10 weeks of rice transplanting could overcome the problem of N-mineralization during crop growth period. Sridevi et al. (2006) observed that mineral nitrogen in the control soil increased from the initial value of 7.84 to $40.42 \mathrm{mg} \mathrm{kg}^{-1}$ by the end of 90 days of incubation.

\section{Availability of macro-nutrients}

Singh et al. (1980) registered increase of total and available $\mathrm{N}$ and also available $\mathrm{K}$ status with the continuous use of FYM under the cropping systems. Dinesh and Dubey (1999) observed that the Nmineralization rates were greater during the first week and decreased with time in all treatments. On an average, the organic manure amended soil leached $156.3 \mathrm{mg} \mathrm{kg}^{-1}$ more $\mathrm{NO}_{3}{ }^{-}+\mathrm{NO}_{2}^{-}$than that unamended control. The net $\mathrm{N}$-mineralization was however, significantly higher in soils amended with organic manures compared to the unamended control. 
Chahal et al. (1984) reported that the bajra-wheat sequence showed a cumulative use of $60 \mathrm{~kg} \mathrm{P}_{2} \mathrm{O}_{5}$ per ha dose raised the available $\mathrm{P}$ level in soil from 17 to 28.6 $\mathrm{kg} \mathrm{P} \mathrm{ha}^{-1}$. Available $\mathrm{N}$ and $\mathrm{K}$ status decreased with continuous cropping from 215 to $132 \mathrm{~kg} \mathrm{ha}^{-1}$ and 616 to $256 \mathrm{~kg} \mathrm{ha}^{-1}$ respectively. Jeevanrao and Dakhore (1994) from a long time manorial experiment on vertisols revealed on increasing in organic carbon, available NPK with the application of $30 \mathrm{~kg} \mathrm{P}_{2} \mathrm{O}_{5} \mathrm{ha}^{-1}, 30 \mathrm{~kg} \mathrm{~K}_{2} \mathrm{O} \mathrm{ha}^{-1}$ and 15 tonnes of FYM ha ${ }^{-1}$.

Pandey et al. (1985) observed that fertilizer $\mathrm{N}$ alone or in combination with $\mathrm{P}$ and $\mathrm{K}$ invariably resulted in the significant increase over control showing positive balance for available $\mathrm{N}$ status of soil. Gupta et al. (1988) found that during wheat growing, organic carbon and available $\mathrm{P}$ increased up to 52 days and thereafter decreased at both the soil depth with application of FYM irrespective of levels. The available $\mathrm{P}$ content of the soil remained in sufficient range with the application of FYM. The available $\mathrm{N}$ content of the soil increased up to 20 days after FYM application and decreased thereafter at all the FYM levels.

Jayaraman (1988) concluded that application of $75 \mathrm{~kg} \mathrm{~N}$ per ha and green leaf manure of leuceana improved organic carbon and $\mathrm{N}$ content of soil as compared to $\mathrm{N}$ fertilizers alone. Lal and Mathur (1988) observed that the available $\mathrm{N}$ in soil was increased significantly in fertilizer treated plots as compared to that of FYM alone and its significant correlation was noticed with total $\mathrm{N}$.

Yaduvanshi (1988) reported improvement in available $\mathrm{P}$ content in soil due to the application of FYM in long term fertilizer experiments, however it decreased in absence of $\mathrm{P}$ application. Verma and Yadav (1988) studied the effect of long term fertilization to rice -wheat sequence for seven years and observed maximum depletion in total $\mathrm{N}$ status of the soil in control (No Po Ko). A negative balance was reported at $\mathrm{N}_{40}$ level. Whereas at higher level of $\mathrm{N}$ (80 and $\left.120 \mathrm{~kg} \mathrm{ha}^{-1}\right)$, considerable build up of soil $\mathrm{N}$ was observed.

Jadhav (1989) reported that the total $\mathrm{N}$ and available $\mathrm{P}$ showed a positive balance under groundnut-wheat sequence whereas a negative balance was observed under sorghum-wheat cropping system. The decline in availability of $\mathrm{K}$ was noticed under sorghum-wheat as well as groundnut-wheat system. Swarup and Singh (1989) during long term experiment on rice and wheat grown in rotation for twenty years observed reduction in available $\mathrm{N}$ from initial values of $225 \mathrm{~kg} \mathrm{ha}^{-1}$ to $120 \mathrm{~kg}$ $\mathrm{ha}^{-1}$ in untreated plots and available $\mathrm{P}$ also decreased from initial value.

Udaysoorian et al. (1989) during long term study observed that the continuous organic manuring for eight years significantly increased soil available $\mathrm{K}$ content in the surface and sub-surface layers. Lal et al. (1990) reported significant increase in total $\mathrm{K}$ in long term application of FYM, fertilizer and lime after 28 years. Prasad et al. (1991) observed that available S and P of soil were interrelated and their availability was increased when $\mathrm{S}$ and $\mathrm{P}$ were applied on combination.

Raghuvanshi et al. (1991) reported that total $\mathrm{N}$ in the soil after 2 years experiment showed a deficit of $13 \mathrm{~kg} \mathrm{~N} \mathrm{ha}^{-1}$ in sorghum-wheat sequence whereas nitrogen status of soil improved in legume cropping sequence. The available $\mathrm{P}$ showed deficit in all cropping sequences while availability of $\mathrm{K}$ was improved in sorghum-wheat cropping sequence. Bansal (1992) observed that the application of K and FYM alone significantly increased the available $\mathrm{K}$ content in soil and further build up was observed with application of 100\% NPK + FYM.

Bhandari et al. (1992) also reported increased availability of $\mathrm{P}$ in soil with the combined use of NPK fertilizer and organic $\mathrm{N}$ source of rice-wheat cropping system. Gupta et al. (1992) reported favorable effect of FYM and N doses in increasing the available $\mathrm{P}$ at all depths under pearl millet-wheat cropping sequence. Kumar and Yadav (1993) noted that the application of K fertilizer increased availability of $\mathrm{K}$ over its initial value, while the treatment without $\mathrm{K}$ fertilizer caused its reduction. The available $\mathrm{K}$ status remained unaffected with the use of different levels on N or NP combinations in rice-wheat cropping sequence.

Naphade et al. (1993) reported that the application of $150 \%$ NPK fertilizer increased the available $\mathrm{P}$ and available K status of soil. Similarly application of FYM along with $100 \%$ NPK increased the same. Dhanorkar et al. (1994) studied that the long term application of FYM and NPK fertilizers over 20 years observed distinct build up in total $\mathrm{K}$ where potassium was applied. The highest total $\mathrm{K}$ was recorded where $56.7 \mathrm{~kg} \mathrm{~K}_{2} \mathrm{O}$ per ha was applied along with FYM.

Mathan et al. (1994) observed that the available nutrient status of the soil after harvest of crops increased significantly by the treatment urea $\left(25 \mathrm{~kg} \mathrm{ha}^{-1}\right)+\mathrm{FYM}$ $\left(7.5 \mathrm{t} \mathrm{ha}^{-1}\right)$. Nambiar (1994) revealed that continuous use of FYM raised available K 1.3 to 5.4 folds over control. 
It was reported that application of fertilizer $\mathrm{K}$ to crops was found inadequate as compared with $\mathrm{K}$ requirement, resulting in over exploitation of native $\mathrm{K}$.

Tyagi and Bhardwaj (1994) studied the effect of long term fertilizer application on the availability of $\mathrm{P}$ which was decreased from 47.5 to $5.8 \mathrm{~kg} \mathrm{ha}^{-1}$ from $0-15 \mathrm{~cm}$ to $75-90 \mathrm{~cm}$ depth respectively. The lowest available $\mathrm{P}$ was found in control while highest content in $150 \%$ NPK treatment. The continuous cropping without fertilization or manuring decreased the available P status of the soil. Malewar and Hasnabade (1995) reported significant increase in available NP and K with continuous application of organic and inorganic fertilizer particularly with FYM + NPK. Sheeba and Chellumuthu (1996) observed that the continuous addition of $\mathrm{P}$ fertilizers increased the concentration of total $\mathrm{P}$ in the soil. Application of $100 \%$ NPK + FYM resulted in buildup of total and available $\mathrm{P}$ status of soil.

Singh et al. (1996) observed that introduction of legume in cropping system increased available soil P. Dudhat et al. (1997) reported that application of FYM alone or in combination with chemical fertilizer significantly increased the residual status of available $\mathrm{N}$ and $\mathrm{P}$ in soil. Singh (1997) reported that continuous cropping with high analysis fertilizer (DAP) tended to decrease available $\mathrm{S}$ content of soil. $\mathrm{N}$ fertilizers application indicated reduced $\mathrm{S}$ availability in soil from initial levels of $22.5 \mathrm{mg} \mathrm{kg}^{-1}$ to $17.1 \mathrm{mg} \mathrm{kg}^{-1}$ after 25 cropping cycles.

Lupwayi and Haque (1998) observed that leaves of leuceana applied at an equivalent rate of $3 \mathrm{t}$ dry matter per ha were significant source of $\mathrm{N}, \mathrm{K}$ and $\mathrm{Mg}$. They further stated that $\mathrm{N}$ in leuceana mineralized in soil more slowly than sesbania and to avoid leaching, erosion, volatilization or denitrification loss of $\mathrm{N}$. Ravanker et al. (1998) reported that the long term application of $100 \%$ NPK dose along with $10 \mathrm{t}$ FYM ha ${ }^{-1}$ enhanced spectacularly the amount of total $\mathrm{N}$ and available NPK of Vertisol under sorghum-wheat sequence.

Santhy et al. (1998) reported higher available $\mathrm{N}$ in treatment $100 \%$ NPK + FYM due to high organic carbon content. They further reported that availability of $\mathrm{N}$ was increased after sorghum-wheat sequence in fertilizer treatment. Tembhare et al. (1998) reported appreciable build up of available soil $\mathrm{P}$ in Vertisol at optimal to super optimal (100 to $150 \%$ NPK) doses. This increase in available $\mathrm{P}$ becomes sharp after 12 cropping cycles and declining trend of available K even at $150 \%$ NPK.
Yadav and Kumar (1998) revealed that the continuous application of NPK fertilizer alone at $100 \%$ recommended level and their combination with FYM increased the available $\mathrm{P}$ in soil over the initial status. Poongothia et al. (1999) reported that the highest content being recorded for the application of $\mathrm{S}$ as gypsum. Application of green leaf manure increased the available $\mathrm{S}$ content of the soil and the effect was more marked in the presence of gypsum. Sharma et al. (2007) noticed that available nutrients (NPK) in the soil were the lowest in the control plot and the highest in the plot under super optimal NPK. Graded doses of NPK significantly increased their availability in soil. And they also reported the significant increase in available nutrient (NPK) content of the soil in the plot receiving $100 \%$ NPK.

\section{Exchangeable Ca and $\mathrm{Mg}$}

Bellakki and Badanur (1997) reported that the increasing trend of exchangeable $\mathrm{Ca}$ and $\mathrm{Mg}$ with the application of FYM. Bellaki et al. (1998) conducted long term experiment for 10 years on Typic Chromusterts and indicated increase in $\mathrm{CEC}$ and exchangeable $\mathrm{Ca}$ contents of the soil due to incorporation of different organic sources of nutrients.

Shrikanth et al. (2000) reported that the application of vermicompost Increase the exchangeable $\mathrm{Ca}$ and $\mathrm{Mg}$ content in soil. Chander et al. (2007) reported that the FYM incorporation, however resulted in to a significant and consistent increase in exchangeable $\mathrm{Ca}$. and also noticed that the exchangeable $\mathrm{Ca}$ content at harvest decreased as compared to that observed during mid of the growth period.

\section{Soil reaction ( $\mathrm{pH})$ and electrical conductivity}

Yaduvanshi et al. (1985) reported noticeable decrease in $\mathrm{pH}$ value as result of continuous manuring over initial value, the decline being pronounced under $100 \% \mathrm{~N}$ and $150 \%$ NPK treatments. A relatively higher soil $\mathrm{pH}$ under $100 \%$ NPK + FYM in comparison with $100 \%$ NPK was also recorded. Kaushal et al. (1986) reported that the $\mathrm{pH}$ of soil rise with depth due to corresponding increase in $\mathrm{CaCO}_{3}$ and to some extent salt content in some lower layers.

Tyagi and Bhardwaj (1994) observed that the continuous use of manures and fertilizers lowered the $\mathrm{pH}$ slightly but with increased soil depth $(0-15,15-30$, and 30-45) the $\mathrm{pH}$ of soil was also increased. They also reported that there is no effect on electrical conductivity. Sinha et al. (1997) 
observed that the continuous use of $\mathrm{N}$ as urea, either alone or in combination with $\mathrm{P}$ and $\mathrm{K}$ decreased the soil $\mathrm{pH}$.

Kumarswami et al. (1998) reported that continuous cropping with different manure and fertilizer schedules for 29 years had no marked change on electrical conductivity and $\mathrm{pH}$ of the soil. Greeval et al. (1999) observed that application of both $\mathrm{P}$ and $\mathrm{K}$ marginally increased the soil $\mathrm{pH}$ both in surface and sub-surface layers than their respective controls. However, after 18 years of crop rotation there was drastic increase in electrical conductivity of soil from 0.56 to $1.29 \mathrm{~d} \mathrm{~S} \mathrm{~m}^{-1}$.

Kadam (1999) reported that the soils were low to very low in soluble salt concentration with electrical conductivity ranging between 0.07 to $0.53 \mathrm{~d} \mathrm{~S} \mathrm{~m}^{-1}$ and the soils developed at upper and middle sector in general have low electrical conductivity. Sharma et al. (2007) noticed that after continuous cropping for 31 years soil $\mathrm{pH}$ and electrical conductivity increased slightly.

\section{Assessment of biological parameters in sorghum- wheat cropping system under long term fertilization}

Linch and Panting (1980) reported that the soil biomass increased during the growth of wheat crop and then decreased to an approximately constant amount. Ritz and Robinson (1988) reported that biomass carbon showed a sharp increase up to approximately 50 days after sowing and decline thereafter, showing no relation with crop growth.

According to Patra et al. (1990) cultivation of wheat crop showed lower biomass $\mathrm{C}\left(689 \mathrm{~kg} \mathrm{ha}^{-1}\right)$ and biomass $\mathrm{N}$ $\left(150 \mathrm{~kg} \mathrm{ha}^{-1}\right)$ in soil as compared to grass land soils $\left(1121 \mathrm{~kg}\right.$ per ha) and $\left(255 \mathrm{~kg} \mathrm{ha}^{-1}\right)$ respectively. Jain et al. (2003) after 25 years of long term fertilizer experiment at livestock Farm JNKVV, Jabalpur it was found that chemical fertilizers did not have any negative impact on Nitrosomonas, Nitrobacter and Azotobacter population although they were enhanced as compared to control. Recommended dose of NPK without S was less effective for Nitrosomonas and Azotobacter. Furthermore FYM application was much superior in maintaining the soil biological health with ultimately reflected on ammonical and nitrate $\mathrm{N}$.

Singh (2003) observed that high status of SMBN and SMBP in the NPK + FYM treated plots followed by NPK and control in Vertisols due to improvement of water soluble fraction in these treatments under continuous cropping of sorghum-wheat sequence while continuous application of fertilizer $\mathrm{N}$ and $\mathrm{P}$ either alone or in combination did not improve active pools of nutrient. Selvi et al. (2004) revealed that amongst the microbes bacterial population was highest as compared to fungi and actinomycetes in soil after cropping sequence of finger millet-maize-cowpea. The application of FYM @ $10 \mathrm{t} \mathrm{ha}^{-1}$ to finger millet annually along with $100 \%$ NPK recorded the highest bacterial counts at the end of rotation followed by $150 \%$ NPK and also observed the mean microbial biomass $\mathrm{C}$ and $\mathrm{N}$ ranged from 238 to $246 \mathrm{mg} \mathrm{kg}^{-1}$ and 27 to $56 \mathrm{mg} \mathrm{kg}^{-1}$ respectively and a gradual increase in biomass $\mathrm{C}$ and $\mathrm{N}$ content of the soil for graded levels of NPK from 50\% to $150 \%$. Further it was also observed that $25 \%$ build up in biomass $\mathrm{C}$ in optimal NPK dose as compared to control.

Considering the importance of soil fertility to improve productivity the study on long term fertilization occupies major role in integrated nutrient management. The agricultural scenario of India was completely changed due to modern intensive agriculture with high doses of fertilizers, insecticides and high yielding fertilizer responsive varieties of crops. Long term fertilizer experiments can be used for monitoring the changes in soil fertility and crop productivity.

\section{Conflict of interest statement}

Authors declare that they have no conflict of interest.

\section{References}

Bansal, K.N., 1992. Potassium balance in multiple cropping systems in a Vertisol at Jabalpur. J. Pot. Res. 8(1), 52-58.

Bellakki, M.A., Badanur, V.P., 1997. Long term effect of integrated nutrient management on properties of Vertisol under dry land agriculture. J. Ind. Soc. Soil Sci. 45(3), 438-442.

Bellakki, M.A., Badanur, V.P., Setty, R.A., 1998. Effect of long term integrated nutrient management on some important properties of Vertisol. J. Ind. Soc. Soil Sci. 46(2), 176-180.

Bhandari, A.L., Sood, A., Sharma, K.N., Rana, D.S., 1992. Integrated nutrient management in a rice-wheat system. J. Ind. Soc. Soil Sci. 40, 742-747.

Bharadwaj, V., Bansal, S.K., Maheshwari, S.C., Omanwar, P.K., 1994. Long term effect of continuous rotational cropping and fertilization on crop yield and soil properties changes in the fraction of N, P \& K of the soil. J. Ind. Soc. Soil Sci. 42(3), 392-397.

Bhattacharya, R., Prakash, V., Kundu, S., Srivastav, A.K., Gupta, H.S., 2004. Effect of long term manuring on soil $\mathrm{OC}$, bulk density and water retention characteristics under 
soybean-wheat cropping sequence in north-western Himalayas. J. Ind. Soc. Soil Sci. 52(3), 238-242.

Blair, G.J., Lefroy, R.D.B., Liale, L., 1995. Soil carbon fractions based on their degree of oxidation and the development of carbon management index (CMI) for agricultural systems. Aust. J. Agril. Res. 46, 1459-1466.

Chahal, R.S., Singh, J., Khore, A.P., 1984. Cumulative direct and residual effect of P, K \& FYM on crop yield and soil characteristics. J. Ind. Soc. Soil Sci. 32(1), 92-96.

Chander, G., Verma, T.S., Sharma, S., 2007. Influence of Boron and FYM on available B \& exchangeable $\mathrm{Ca}$ and their removal by cauliflower in the Boron deficient soils of Himachal Pradesh. J. Ind. Soc. Soil Sci. 55(1), 62-66.

Chesnin, L., Yein, C.H., 1950. Turbidimetric determination of available sulphates. Soil Sci. Soc. Am. Proc. 15, 149-157.

Consistantinides, M., Fownes, J.H., 1994. N mineralization from leaves and litter of tropical plants relationship of $\mathrm{N}$, lignin and soluble polyphenol concentrations. Soil Biol. Biochem. 26, 52-55.

Dhanorkar, B.A., Borkar, D.K., Puranic, R.B., Joshi, R.P., 1994. Forms of soil $\mathrm{K}$ as influenced by long term application of FYM \& NPK in Vertisol. J. Pot. Res. 10(1), 42-48.

Dinesh, R., Dubey, R.P., 1999. N-mineralization rates and kinetics in soils amended with organic manures. J. Ind. Soc. Soil Sci. 47(3), 421-425.

Dixit, K.G., Gupta, B.R., 2000. Effect of FYM, chemical and biofertilizers on yield and quality of rice and soil properties. J. Ind. Soc. Soil Sci. 48(4), 773-780.

Dudhat, M.S., Malavir, D.D., Mathukia, R.K., Khanpara, V.P., 1997. Effect of nutrient management through organic and inorganic sources on growth, yield, quality and nutrient uptake by wheat. Ind. J. Agron 42(3), 455-458.

Eak, H.V., Stewart, B.A., 1998. Effect of long term cropping on chemical aspects of soil quality. J. Sustain. Agril. 12(2/3), 5-20.

Greval, K.S., Singh, D., Mehta, S.C., Karwasra, S.P.S., 1999. Effect of longterm application of fertilizers on physicochemical properties of soil. J. Ind. Soc. Soil Sci. 47(3), 538-541.

Gupta, A.P., Narwal, R.P., Antil, R.S., Dev, S., 1992. Sustaining soil fertility with OC, N, P and K by using FYM and fertilizer $\mathrm{N}$ in semi-arid zone. Arid Soil Res. Replic. 6(3), 243-251.

Gupta, A.P., Antil, R.S., Narwal, R.P., 1988. Effect of FYM on $\mathrm{OC}$, available $\mathrm{P}$ and $\mathrm{P}$ content of soil during different periods of wheat growth. J. Ind. Soc. Soil Sci. 36, 269-273.

Hutchinson, G.L., 1995. Biosphere-atmosphere exchange of nitrogen oxides. In: Soils and Global Change (Eds.: Lal et al.). Adv. In soil Sci. CRC press, Boca Raton, FL. pp. 219-235.

Jadhav, A.S., 1989. Nutrient balance with reference to fertilizer management under wheat based cropping system. J. Maharashtra Agric. Univ. 14(3), 288-291.

Jain, D., Rawat, A.K., Khare, A.K., Bhatnagar, R.K., 2003. Long term effect of nutrient sources on Azotobacter, nitrifier population and nitrification in Vertisols. J. Ind.
Soc. Soil Sci. 51(1), 35-37.

Jayaraman, S., 1988. Effect of Leuceana leaf manuring on available N and OC of rice soil. Ind. J. Agron. 33(3), 324325.

Jeevanrao, K., Dakhore, R.C., 1994. Nutrient changes in Vertisols under sorghum-wheat rotation for 5 years. J. Soils Crops. 4(2), 108-112.

Kadam, A., 1999. Land evaluation for planning land use at village level a case study inNagpur district. M. Sc. (Agri.) Thesis (unpub.), Dr. P.D.K.V. Akola.

Kamalakumari, K., Singaram, P., 1996. Effect of continuous application of FYM and NPK on fertility status of soil, yield and nutrient uptake in maize. Madras Agric. J. 83(3), 181-184.

Kaushal, G.S., Tembhore, G.R., Sinha, S.B., 1986. Morphology and taxonomy of black soil under Bargi irrigation project in Madhya Pradesh. J. Ind. Soc. Soil Sci. 34(2), 329-333.

Kukreja, K., Mishra, M.M., Dhankar, S.S., Kapoor, K.K., Gupta, A.D., 1991. Effect of long term manure application on microbial biomass. J. Ind. Soc. Soil Sci. 39, 685-688.

Kumar, A., Yadav, D.S., 1993. Effect of FYM on $\mathrm{N}$ use efficiency in maize-wheat sequence under rain fed condition. Bull. J. Ind. Soc. Soil Sci. 13, 318-325.

Kumarswamy, K., Venureddy, R., Babu, K., 1998. Cumulative effect of continuous cropping and manuring of sugarcane on organic matter and NPK status of the soil. J. Ind. Soc. Soil Sci. 40(2), 47-49.

Kundu, S., Barman, K.K., Singh, M., 2000. Effects of fertilizer $\mathrm{N}$ rates on soil $\mathrm{N}$ uptake and recovery of applied $\mathrm{N}$ by wheat in a Typic Haplusterts. J. Ind. Soc. Soil Sci. 48(2), 287-291.

Lal, S., Mathur, B.S., Singh, K., 1990. Effect of long term fertilization, manuring and liming of an Alfisol on maizewheat and soil properties III form of K. J. Ind. Soc. Soil Sci. 38(1), 21-26.

Lupwayi, N.Z., Haque, I., 1998. Mineralization of N, P, K, Ca and $\mathrm{Mg}$ for Sesbania and Leucerna leaves varying in chemical composition. Soil Sci. Biochem. 30(3), 337-343.

Lynch, J.M., Panting, L.M., 1980. Cultivation and the soil biomass. Soil Biol. Biochem. 12, 29-33.

Malewar, G.V., Hasnabade, A.R., 1995. Effect of long term application of fertilizers and organic sources on some properties of Vertisol. J. Maharashtra Agric. Univ. 20(2), 285-286.

Mathan, K.K., Francic, J., Arunachlam, L., 1994. Influence of integrated nutrient management on yield, protein content and uptake of nutrient by pigeon pea. J. Ind. Soc. Soil Sci. 42(4), 558-561.

Mishra, B., Sharma, P.K., Bronson, K.F., 2001. Kinetics of wheat straw decomposition and $\mathrm{N}$-mineralization in rice field soil. J. Ind. Soc. Soil Sci. 49(2), 249-254.

Nambiar, K.K.M. 1994. Soil fertility and crop productivity under long term fertilizer use in India. ICAR, New Delhi.

Naphade, K.T., Deshmukh, V.N., Rewatkar, S.S., Solanke, B.V., 1993. Grain yield and nutrient uptake by irrigated wheat grown on Vertisol under various nutrient levels. J. 
Ind. Soc. Soil Sci. 41(2), 370-371.

Olsen, S.R., Cole, W.R., Wathable, F.S., 1954. Estimation of available $\mathrm{P}$ by extraction with sodium bicarbonate. United States Department of Agriculture Circular 939. 19p.

Pandey, S.P., Shankar, H., Sharma, V.K., 1985. Efficacy of some organic and inorganic residues in relation to crop yields and soil characteristics. J. Ind. Soc. Soil Sci. 33, 179-183.

Patra, D.D., Brookers, P.C., Coleman, K., Jenkinson, P.S., 1990. Seasonal changes of soil biomass in arable and grass land soil, which have been under uniform for many years. Soil Biol. Biochem. 22(6), 739-742.

Poongothia, S., Savitri, P., Vennila, R.K., Joseph, B., 1999. Influence of gypsum and green leaf manure application on rice and on soil deficient in S. J. Ind. Soc. Soil Sci. 47(1), 96-99.

Prasad, A., Totey, N.G., Kothari, P.K., Bhowmi, A.K., 1991. Effect of added free leaves on the composition of humus and availability of nutrient in soil. J. Ind. Soc. Soil Sci. 39(3), 429-434.

Raghuvanshi, R.K.S., Umat, R., Nema, M.L., Dubey, D.P., 1991. Balance sheet of N, P \& K in soil as influenced by wheat based crop sequence. Ind. J. Agron. 36(3), 322-325.

Ravankar, H.N., Naphade, K.T., Puranik, R.B., Patil, R.T., 1998. Long term changes in soil fertility status under sorghum-wheat system on a Vertisol (Eds.: Swarup, Reddy, Prasad). All India Coordinated Research Project on long term fertilizer experiment. IISS Publication. pp.292-297.

Ritz, K., Robinson, D., 1988. Temporal variations in soil microbial biomass carbon and nitrogen under a spring Barly crop. Soil Biol. Biochem. 20(5), 625-630.

Santhy, P., Jayasreeshankar, P., Mathuvel, P., Selvi, D., 1998. Long term fertilizer experiment status of $\mathrm{N}, \mathrm{P} \& \mathrm{~K}$ fractions in soil. J. Ind. Soc. Soil Sci. 46(3), 395-398.

Sarkar, M.C., Uppal, K.S., Rana, D.S., Banerjee, N.K., 1994. Fate of ${ }^{15} \mathrm{~N}$ urea applied to wheat grown under upland irrigated condition on a Typic Ustochrept. J. Ind. Soc. Soil Sci. 42(2), 267-271.

Schimel, D.S., Coleman, D.C., Horton, K.A., 1985. Soil organic matter dynamics in paired range land and crop land toposequences in north Dakata. Geoderma. 36, 201204.

Selvi, D., Santhy, P., Dhakshinamoorthy, M., Maheshwari, M., 2004. Microbial population and biomass in rhizosphere as influenced by continuous intensive cultivation and fertilization in Inceptisol. J. Ind. Soc. Soil Sci. 52(3), 254257.

Sharma, M., Mishra, B., Singh, R., 2007. Long term effect of fertilizers and manure on physical and chemical properties of Mollisol. J. Ind. Soc. Soil Sci. 55(4), 523-524.

Sharma, M.P., Bali, S.V., Gupta, D.K., 2000. Crop yield and properties of Inceptisol as influenced by residue management under rice-wheat cropping sequence. J. Ind. Soc. Soil Sci. 48(3), 506-509.

Sheeba, S., Chellumuthu, S., 1996. Organic carbon and total nutrient content of Inceptisol under long term fertilization.
Madras Agric. J. 10, 650-652.

Shrikanth, K., Srinivasamurthy, C.A., Siddaramappa, R., Ramakrishna, P.V.R., 2000. Direct and residual effect of enriched composts, FYM, vermicompost and fertilizer on properties of an Alfisol. J. Ind. Soc. Soil Sci. 48(3), 496499.

Singh, L., Verma, R.N.S., Lohia, S.S., 1980. Effect of continuous application of FYM and chemical fertilizers on some soil properties. J. Ind. Soc. Soil Sci. 28(2), 170-172.

Singh, M.V., 2003. Organic pools and dynamics in relation to land use, tillage and agronomic practices on the maintenance of soil fertility. IISS, Bhopal. pp.1-92.

Singh, V., 1997. Sulphur fertilization reduces HCN content of sorghum. Sulphur in Agric. 7, 12-14.

Singh, Y., Chaudary, D.C., Singh, S.P., Bhardwaj, A.K., Singh, D., 1996. Sustainability of rice-wheat sequential cropping through introduction of legume crops and green manure crop in the system. Ind. J. Agron. 41(4), 510-514.

Sinha, S.K., Singh, V.N., 1997. Effect of continuous application of manures and fertilizers on available nutrients in an alluvial soil. J. Res. (BAV). 9(2), 163166.

Sridevi, S., Srinivas, K., Sharma, K.L., 2006. Nitrogen mineralization from soil amended with Gliricidia and sorghum residues. J. Ind. Soc. Soil Sci. 54(3), 345-347.

Swarup, A., Singh, K.N., 1989. Effect of 12 years rice-wheat cropping sequence and fertilizer use on soil properties and crop yields in a sodic soil. Field Crop Res. 21, 277-287.

Tembhare, B.R., Dwivedi, A.K., Tiwari, A., 1998. Effect of continuous cropping and fertilizer use on crop yield and fertility of a Typic Haplusterts. All India Coordinated Reseach Project on Long Term Fertilizer Experiment (Eds: Swarup, Reddy and Prasad). ISS, Bhopal. pp.221228.

Tiwari, R.C., Verma, V.N., Mishra, A.K., 1995. Effect of long term cropping systems on chemical characteristics of soil profiles. J. Ind. Soc. Soil Sci. 43(2), 278-279.

Tyagi, V.V., Bhardwaj, V., 1994. Effect of continuous cropping and fertilization on the status of available N, P \& $\mathrm{K}$ in Mollisol. J. Pot. Res. 10(4), 384-391.

Udayasoorian, C., Sreeramulu, U.S., Krishnamoorthy, V., 1989. Effect of continuous manuring and fertilization in rice-rice cropping system. Madras Agric. J. 78(5-8), 204206.

Vaidya, P.H., Gabhane, V.V., 1998. Availability of nutrients in Vertisols as influenced by sorghum-wheat cropping sequence. J. Soils Crops. 8(1), 70-72.

Verma, L.P., Yadav, D.S., 1988. Effect of long term fertilization on soil nitrogen balance under rice-wheat cropping system. Ind. J. Agron. 33(3), 317-318.

Verma, L.P., Yadav, D.S., Singh, R., 1987. Effect of continuous fertilizer application on fertility status of soil. J. Ind. Soc. Soil Sci. 35(1), 754-756.

Whitbread, A.M., Blair, G.J., Lefroy, R.D.B., 1996. The impact of cropping history on soil physical properties and soil carbon. In: Proceedings of Australian and New Zealand National Soil Conference. 1-4 July, 1996, 
Melbourne, Australia. ASSSI, NZSSS. pp.311-312.

Yadav, D.S., Alok Kumar, 1998. Integrated use of organics and inorganics in rice-wheat cropping system for sustainable production IPNS system for sustainable productivity (Eds.: Swarup, Reddy and Prasad). IIPSS Publication. p.247.
Yaduvanshi, H.S., 1988. Changes in available P in Alfisol under prolonged manuring and intensive cropping. J. Ind. Soc. Soil Sci. 36(4), 719-724.

Yaduvanshi, H.S., Tripathi, B.R., Kanwar, B.S., 1985. Effect of continuous manuring on some soil properties of Alfisol. J. Ind. Soc. Soil Sci. 33, 700-703.

\section{How to cite this article:}

Puli, M. R., Katkhar, R. N., Mitnala, J., Rao, B. R., 2016. Assessment of chemical and biological parameters in sorghum-wheat cropping sequence under long term fertilization - A review. Int. J. Curr. Res. Biosci. Plant Biol. 3(6), 149-156. doi: http://dx.doi.org/10.20546/ijcrbp.2016.306.018 